\title{
O Mar Territorial do Estado Brasileiro.
}

\author{
Dalmo de Abreu Dallari \\ Professor Titular de Teoria do Estado na \\ Faculdade de Direito da Universidade de \\ São Paulo.
}

I. O CONCEITO DE MAR TERRITORIAL E SUA SIGNIFICAÇÃO. a) A Disciplina Jurídica da Utilização do Mar Contiguo aos Estados. b) Mar Territorial e Soberania. c) Conclusões Preliminares. II. COMPETENCIA PARA FIXAR A EXTENSÄO DO MAR TERRITORIAL. a) As Fontes do Direito Internacional. b) Os Atos Unilaterais. c) Precedentes Relativos à Forma de Fixação do Mar Territorial. III. A AMPLIAÇÃO DO MAR TERRITORIAL E SUAS CONSEQUENCIAS JURIDICAS. a) Ampliação do Tierritório. b) Ampliação da Soberania. c) Conflitos com Direitos de Outros Estados. IV. O MAR TERRITORIAL BRASILEIRO. a) Variações da Extensão do Mar Territorial. b) Formas de Alteração da Extensão. c) Concordância e Conflito com Outros Estados. V. PERSPECTIVAS A CURTO E A LONGO PRAZO. a) Afirmação de Novos Conoitos. b) Impossibilidade de Extensões Uniformes. c) Maior Disciplina Juridica. VI. CONCLUSOESS FINAIS.

I. O CONCEITO DE MAR TERRITORIAL E SUA SIGNIFICAÇAO.

a. A Disciplina Jurídica da Utilização do Mar Contíguo aos Estados.

1. A incorporação de uma faixa de mar ao território dos Estados ribeirinhos é prática várias vezes centenária, que todos reconhecem como necessária e justa. Entretanto, à medida em que se ampliaram as possibilidades de utilização do mar, de suas riquezas, do solo e do sub-solo marítimos, o problema do relacionamento dos Estados litorâneos com o 
mar, sob o aspecto jurídico, foram-se tornando cada vez mais complexos, atingindo agora um ponto de extrema dificuldade, começando já a influir seriamente nas próprias relações internacionais.

Para se ter idéia da complexidade do problema, bastará uma rápida menção aos conceitos que vêm sendo utilizados para designar diferentes aspectos da faixa de mar contígua ao território dos Estados: mar territorial, águas jurisdicionais, plataforma continental, plataforma submarina, plataforma continental submarina, zona contígua, zona de pesca, zona de segurança, zona de conservação, mar patrimonial, além de outros usados como sinônimos ou designativos de pequenas diferenças.

Quanto aos motivos de interêsse dos Estados pelo mar adjacente também se verificou a mesma complexidade crescente. De fato, enquanto que de início a razão exclusiva era a segurança, agora são muitos os motivos alegados, podendo-se fazer uma enumeração das razões invocadas com mais frequência, a saber:

a) necessidades e interêsses econômicos, principalmënte considerando as atividades da pesca, fundamentais para a economia de alguns Estados e muito importantes para outros, além da exploração de outras riquezas existentes no mar ou no subsolo marítimo, tendo-se acentuado a significação econômica, ultimamente, pela ampliação das possibilidades de extração de petróleo do fundo do mar;

b) motivos de natureza fiscal, compreendendo tanto a necessidade de controle aduaneiro, quanto a possibilidade da imposição de tributos aos estrangeiros que desejem explorar as riquezas da faixa do oceano contígua ao território do Estado;

c) a necessidade de conservação de espécies marítimas, impedindo a pesca indiscriminada, em épocas impróprias e com o uso de técnicas inadequadas, ou em quantidades excessivas, o que levaria à dizimação de cardumes e, inevitavelmente, à extinção de muitas espécies em curto prazo;

d) razões de ordem sanitária, muito enfatizadas nos últimos tempos, pela tomada de consciência dos riscos e inconvenientes da poluição marítima; 
e) a necessidade de suprir as deficiências dos Estados desprovidos de território submerso, quando tais Estados não dispõem de plataforma continental submarina ou quando esta é muito reduzida;

f) a conveniência e a necessidade de utilização das vias oceânicas para comunicações, não só para a passagem de navios mas também para a colocação de cabos submarinos e a instalação de aparelhos que a técnica moderna vem criando;

g) um motivo de ordem geográfica, invocado pelos Estados centro-americanos da costa do Pacífico, que é a necessidade de incluírem no seu mar territórial a Corrente de Humboldt, junto à qual se concentra a parte principal da fauna marinha da região.

Todos esses motivos, invocados em conjunto ou separadamente, somam-se às razões de segurança e dão origem a múltiplas reivindicações, variando a pretensão dos Estados conforme os objetivos almejados. Assim, quando a finalidade é apenas a segurança o contrôle sobre o mar adjacente não é exercido da mesma forma que se exerce quando são visados fins econômicos. $\mathrm{E}$ dessa multiplicidade de objetivos é que decorre a variedade de conceitos tendentes a disciplinar as relações de um Estado com o mar adjacente.

\section{b. Mar Territorial e Soberania.}

2. De todos os conceitos propostos e utilizados, o mais importante, sem dúvida, é o de mar territorial. Com efeito, através dos demais o que se afirma é o poder limitado do Estado, restrito a determinados objetivos ou a uma faixa geralmente não muito ampla. Evidentemente, esses conceitos, pelo fato de afirmarem direitos exclusivos, significam limitações aos direitos dos demais Estados, razão pela qual, quando fixados pelo Estado interessado e não mediante tratados, caracterizam a fixação unilateral dos próprios direitos. Entretanto, pela extensão dos direitos incluídos no conceito de mar territorial, este é o que afeta com mais gravidade os interêsses dos Estados que se dedicam à utilização intensiva do mar, razão pela qual é o que desperta maiores controversias.

Como bem assinala Vicente Marotta Rangel, é muito antiga a tese da incorporação do mar territorial ao território do Estado, podendose dar como exemplo e confirmação dessa antiguidade um pacto de deli- 
mitação de fronteiras entre a Noruega e a Rússia celebrado em 3 de junho de 1326. Modernamente, essa tese tem aceitação generalizada no Direito Internacional, podendo-se conceituar o mar territorial como "a banda de mar paralela à costa, onde o Estado ribeirinho detém - com ressalva do direito de trânsito inocente dos navios mercantes estrangeiros poderes similares aos que exerce em seu território terrestre". Assim, pois, "é o mar territorial parte do território do Estado, que margina, e é sujeito à soberania desse Estado" 1 . Este é o dado fundamental, que torna o conceito de mar territorial substancialmente diverso de todos os demais relativos ao mar: o mar territorial está sujeito à soberania do Estado a que pertence. E bem verdade que a plataforma continental também está sujeita à soberania, mas nesse conceito se compreende apenas a continuação do continente sob o mar, numa profundidade não superior a, aproximadamente, duzentos metros. Daí a importância muito maior do mar territorial, que inclui as águas e tudo o que exista abaixo e acima delas.

E que significa afirmar-se que o Estado exerce soberania sobre o mar territorial ? A noção de soberania é, atualmente, bastante controvertida na Teoria do Estado e no Direito Internacional, não obstante continuar sendo largamente empregada na prática e na doutrina. Assim é que KaPlan e KatZenbach dizem que "não há no Direito Internacional um termo mais embaraçoso que soberania", acrescentando que o seu uso impreciso e indisciplinado "talvez se deva ao fato de haver-se tornado um símbolo altamente emocional", largamente utilizado para conquistar simpatias em face das tendências nacionalistas que vêm marcando nossa época ${ }^{2}$.

A soberania, na sua origem histórica, foi uma concepção de caráter exclusivamente político, afirmando-se então como o "poder incontrastável de querer coercitivamente". Entretanto, desde o fim do século passado já se procurou dar-lhe um conteúdo jurídico, que lhe fornecesse outra justificativa que não a mera força material. Mais tarde, por volta da se-

1. VICENTE MAROTTA, RANGEL, Natureza Jurídica e Delimitação do Mar Territorial, São Paulo, 1965, págs. 18 e 84. Nessa obra, em que o assunto é estudado exaustivamente e com grande rigor científico, o autor demonstra a aceitação quase unânime, nos tratados e na doutrina, de que o mar territorial integra, para todos os efeitos, o território do Estado contíguo, ficando sujeito, portanto, à soberania deste.

2. MORTON A. KAPLAN e NICOLAS DE B. KATZENBACH, Fundamentos Politicos do Direito Internacional, Rio de Janeiro, ed. Zaoar, 1964, pág. 149. 
gunda década do século XX, sobretudo por influência da tragédia que fôra a primeira guerra mundial, ocorre mesmo uma tentativa, sem êxito, de eliminar da linguagem política e jurídica a soberania, considerada expressão do individualismo e do egoísmo dos Estados. Tenta-se, depois disso, estabelecer uma diferenciação entre soberania política e soberania jurídica, concebendo-se esta como "o poder de decidir em última instância sobre a eficácia do Direito". Este conceito afirmaria o poder soberano como um poder jurídico, disciplinado pelo Direito na sua aquisição, no seu exercício e na sua perda, com o que se eliminaria o arbîtrio da força. Como os fatos tem demonstrado, não se pode sustentar que a soberania tenha perdido seu caráter político, como expressão de força, subordinăndo-se totalmente a uma disciplina jurídica. Entretanto, essa afirmação da soberania como um direito tem sido útil, quando menos para ressaltar o caráter anti-jurídico e injusto da utilização da força como forma de solução de conflitos de interêsses entre Estados, contribuindo para a formação de uma nova consciência, que repudia o uso arbitrário da fôrça 3 .

De fato, porém, apesar do progresso verificado, a soberania continua a ser concebida de duas maneiras distintas: ou como sinônimo de independência, e assim tem sido invocada pelos dirigentes dos Estados que desejam afirmar, sobretudo ao seu próprio povo, não serem mais submissos a qualquer potência estrangeira; ou como expressão de poder jurídico mais alto, significando que, dentro dos limites de jurisdição do Estado, este é que tem o poder de decisão em última instância sobre a eficácia de qualquer norma jurídica. Como fica evidente, a afirmação de soberania, no sentido de independência, apoia-se no poder de fato que tenha determinado Estado, de fazer prevalecer sua vontade dentro de seus limites jurisdicionais. A conceituação jurídica de soberania considera irrelevante, em princípio, o potencial de força material, uma vez que se baseia na igualdade jurídica dos Estados a pressupõe o respeito recíproco

3. Sobre a evolução do conceito de soberania veja-se GEORG JELLINEK, Teoria General del Estado, Buenos Aires, Editorial Albatros, 1954, págs. 328 e seguintes; MIGUEL REALE, Teoria do Direito e do Estado, São Paulo, Ed. Martins, 1960 (2." edição), págs. 138 e seguintes; HAROLDO VALLADÃO, Democratização e Socialização do Dineito Internacional, Rio de Janeiro, Ed. José Olympio, 1961, págs. 53 e seguintes; A. MACHADO PAUPERIO, O Conceito Polêmico de Soberania, Rio de Janeiro, Ed. Forense, 1958 (2. ${ }^{a}$ edição). Também trato do assunto em meu livro Elementos de Teoria Geral do Estado, São Paulo, Ed. Saraiva, 1972, págs. 65 e seguintes. 
como regra de convivência. Neste caso, a prevalência da vontade de um Estado mais forte, nos limites jurisdicionais de um mais fraco, é sempre um ato irregular, anti-jurídico, configurando uma violação de soberania, passível de sanções jurídicas. E mesmo que estas sanções não possam ser aplicadas imediatamente, por deficiência de meios materiais, o caráter anti-jurídico da violação permanece, podendo servir de base a futuras reivindicações, bem como à obtenção de solidariedade de outros Estados.

\section{c. Conclusões Preliminares.}

Em face disso tudo, podem ser fixadas algumas conclusões preliminares, que será necessário ter em conta na consideração dos demais aspectos do problema:

a) O conceito de mar territorial é o de maior amplitude, dos que se referem à utilização do mar pelos Estados costeiros. Por ele se afirma que uma faixa de mar, adjacente ao território do Estado, é parte integrante do território e, como tal, sujeita à soberania do Estado.

b) A soberania, do ponto de vista estritamente político, é expressão de um poder de fato, existindo na medida em que, pela força, um Estado possa fazer prevalecer sua vontade. Entretanto, do ponto de vista jurídico, a soberania independe da eventual ineficácia de fato, caracterizando-se sempre suas violações como atos anti-jurídicos, passíveis de sanções e aptos a qualificar o violador como ofensor dos direitos dos Estados.

c) A impossibilidade de aplicar sanções imediatas contra o violador de seu mar territorial não implica, para um Estado, a perda de soberania, não contribuindo, também, para tornar regular o procedimento do violador.

II. COMPETENCIA PARA FIXAR A EXTENSÃO DO MAR TERRITORIAL.

a. As Fontes do Direito Internacional.

4. A circunstância de não existir um órgão de Poder Legislativo internacional, que torne possível o reconhecimento das normas de direito positivo segundo um critério puramente formal, exige um esforço maior para a identificação das normas legítimas. $\mathrm{Na}$ verdade, como bem obser- 
vou SCELle, existe, na sociedade internacional, um corpo legislativo interestatal invertebrado, não institucionalizado pela ordem jurídica internacional mas funcionando efetivamente ${ }^{4}$. E, por não haver uma organização desse poder legislativo, quem atua na condição de órgãos são os próprios Estados, através de atos unilaterais que tornam certas, por uma forma precisa, as normas de direito positivo internacional. (A expressão "atos unilaterais", nesse caso, tem sentido amplo, compreendendo, inclusive, os atos de adesão a tratados, embora estes sejam bi ou multi-laterais).

Por esse motivo, a verificação da legitimidade do aparecimento e do acertamento de uma norma de direito público internacional exige que se faça um prévio estudo das fontes desse direito, para que se saiba se a norma em questão é originaria de uma fonte reconhecida como tal. Em outras palavras, deve-se proceder à prévia verificação dos meios regulares de criação de normas jurídicas internacionais, para, num segundo momento, ser possível concluir se a norma tornada certa por um Estado encontra apoio no sistema jurídico internacional.

Em excelente estudo sobre as fontes do direito internacional, ALFREDo Hercowitz começa por salientar que esse direito, fundado sobre a base do consentimento dos Estados, se divide em duas partes fundamentais: o direito que recebeu aprovação tácita (considerado no exame dos princípios consuetudinárioș) e o direito internacional aceito expressamente, em instrumentos jurídicos, tais como os tratados e as convenções. Assim, pois, a norma jurídica internacional deve estar apoiada no direito escrito, cujos principais instrumentos são os tratados e as convenções, ou então no costume. Observou Hercowitz que, não havendo regras escritas que claramente definam uma situação, recorre-se a outros elementos, que são: em primeiro lugar, as normas consuetudinárias; em segundo, as regras contidas nas convenções estabelecidas em acordos ou conferências internacionais; em terceiro lugar, as práticas ou usos mais ou menos gerais; em quarto, os princípios gerais do Direito Internacional e, por último, os preceitos de justiça internacional. Pondo de parte a discutivel hierarquia desses elementos, importa ressaltar que o próprio Hercowitz reconhece que os precedentes diplomáticos, as sentenças arbitrais ou de tribunais internacionais, as decisões dos tribunais nacionais em matéria

4. GEORGES SCELLE, Manuel de Droit International Public, Paris, 1948, págs. 600 e 601 . 
internacional, assim como a opinião dos publicistas de autoridade, não podem chamar-se com propriedade fontes do Direito Internacional, mas, com mais precisão, elementos de interpretação, enquanto esclarecem o direito existente, como subsidiários das normas jurídicas 5

Assim, pois, a rigor as fontes do Direito Internacional se reduzem a duas espécies: $1 .^{\mathrm{a}}$ - as fontes escritas, representadas pelos tratados, acordos, convenções e demais instrumentos de que se valem os Estados para expressar formalmente sua vontade soberana: $2 .^{\mathrm{a}}-o$ costume.

5. As fontes escritas oferecem maior facilidade para que se tenha certeza do direito, sendo essa a sua maior vantagem. Apesar de todas as dificuldades que possam ser encontradas para a interpretação das normas escritas e para sua perfeita adequação a cada caso concreto, elas representam sempre um ponto de partida objetivo, delimitando o âmbito das controvérsias e tornando mais fácil a busca das intenções dos Estados. Por tais motivos, um dos efeitos principais da existência de regras escritas é a colocação do costume num plano secundário, ou para revogá-lo ou, então, para situá-lo apenas como elemento auxiliar da interpretação.

Relativamente ao alcance das regras escritas, é importante assinalar dois efeitos fundamentais:

$10^{\circ}$ - elas obrigam os signatários do instrumento jurídico, bem como aqueles que formalmente aderem às suas regras. $O$ Estado que houver celebrado um tratado fixando normas sobre determinada matéria não pode, posteriormente, invocar a seu favor um costume contrário àquelas normas. Existe, ainda, uma estreita vinculação entre o direito internacional e o direito interno dos Estados, de tal sorte que não se admitem contradições entre a ordem jurídica interna e os preceitos internacionais que o Estado tiver solenemente fixado ou aos quais houver formalmente aderido. Da mesma forma, as normas de direito interno devem valer como revelação da vontade do Estado, quando influírem no seu comportamento externo, embora não se admita a invocação do preceito interno como regra obrigatória em âmbito internacional.

5. ALFREDO HERCOWITZ, De la lei internacional: sus fuentes. La lei natural. La costumbre. Los tratados publicos, in Anales del Instituto de Derecho de Gentes, Rosário (Argentina), 1942, págs. 127 a 161. 
$2 .^{\circ}$ - as regras escritas só obrigam os Estados signatários dos documentos que as consagram e os que houverem formalmente aderido às mesmas regras. Se dois ou mais Estados celebrarem um tratado podem invocá-lo nas suas relações, não podendo, entretanto, exigir a obediência de terceiros não signatários ou não aderentes, assim como estes não podem invocar a seu favor aquele tratado. Por tal motivo, mesmo que se trate de um acordo multilateral, reunindo grande número de Estados, não pode ser imposto à obediência dos que não o integram. $O$ que pode ocorrer é que um tratado dessa espécie acabe determinando comportamentos uniformes e reiterados, passando a valer como costume para os Estados não signatários e não-aderentes. Para isso, entretanto, é necessário que se verifiquem todos os pressupostos caracterizadores do costume, sobre os quais se discorrerá em seguida.

6. A caracterização do costume como fonte de direito não é tarefa das mais fáceis no âmbito interno dos Estados, ganhando, entretanto, complexidade ainda maior no âmbito internacional. Com efeito, internamente existe a possibilidade de se fixarem critérios legais e jurisprudenciais para a identificação do costume e o estabelecimento dos termos de sua validade e eficácia, o que dificilmente se consegue no plano internacional. Em razão dessa dificuldade é que os grupos sociais que ainda permanecem regidos pelo direito costumeiro são apenas aqueles mais primitivos cuja vida é menos dinâmica e cuja organização social sofre menos transformações. Essa preferência pelo registro formal e escrito das normas jurídicas não pode, todavia, ter o mesmo reflexo nas relações internacionais, por faltar aqui um órgão de poder legislativo, como tambem por inexistir um poder coercitivo capaz de assegurar a eficácia das normas formalmente positivadas.

$\mathrm{Na}$ vendade, em termos rigorosos a própria observância das regras jurídicas, escritas ou não, nas relações internacionais é a expressão de uma norma fundamental, que para alguns é uma regra de Direito Natural, enquanto que para outros é já a aceitação de um costume.

Qual seria, entretanto, o meio de identificar determinado comportamento como um costume? Estudando o assunto, diz Próspero Fedozzi que o costume internacional consta de dois elementos característicos: um deles é o uso e o outro é a opinião jurídica ou a necessidade. Reunindo esses elementos, o costume vai-se conformando através de reiterações de 
atos estatais de conteúdo idêntico, até criar no Estado a conviçcão de que aquele comportamento retierado já se converteu em norma obrigatória, incorporada ao Direito Internacional. $\mathrm{Na}$ opinião de FEDOZZI é necessário ainda que os Estados aceitem e acatem tal procedimento como um dever imposto à obediência de todos. Assim, pois, para elevar um fato à categoria de costume não é suficiente a concordância dos atos legislativos ou da jurisprudência, sendo indispensável que exista paralelamente o elemento psicológico, que emana da idéia de cumprimento de um dever internacional 6

Considerando o problema à luz do comportamento dos Estados e da situação política e jurídica mundial na segunda metade do século XX, KAPLAN e KATZENBACH sustentam que o costume não é, propriamente, uma fonte de Direito, mas sua invocação é apenas um processo de derivar regras a partir de comportamentos passados. Em sua opinião, dizer que o costume é fonte de Direito é dizer apenas que os autores de decisões invocam práticas passadas para legitimarem as decisões atuais. Como se verifica, essa concepção representa, em última análise, o deslocamento do costume para a condição de elemento auxiliar da interpretação e da aplicação das normas. Apesar disso, entretanto, os mesmos autores procuram apontar algumas peculiaridades que tornam possível a identificação do costume como fator de influência na ordem jurídica internacional. A principal característica, a seu ver, é a obrigatoriedade do costume, independente de considerações de momento. Neste ponto ele difere do uso, que tem caráter utilitário e deriva da oportunidade, deixando de prevalecer quando já não for oportuno. Baseando-se em reiterados comportamentos passados, a norma de direito costumeiro deve ter clareza e tradição, impondo-se obrigatoriamente à obediência, sem considerações de oportunidade. Isso não quer dizer que o costume seja estático e imutável. Desde que se afirmou o conceito de soberania os Estados ficaram livres para introduzir corportamentos novos, enquanto não violem uma regra positiva de Direito Internacional. E o Estado que sustentar haver ocorrido essa violação assume o ônus de provar tal afirmativa.

Quando ocorre essa mudança de comportamento, não é indispensável que os demais Estados manifestem sua concordância, podendo esta ser considerada implícita na ausência de reclamação ou de recusa. E pa-

6. PRÓSPERO FEDOZZI, Introduzione al Diritto Internazionale, Padova, 1933, pág. 138. 
ra que seja possível essa inovação com maior probabilidade de obtenção do consentimento geral, é necessário que a mudança não seja repentina e radical. Assim concluem Kaplan e Katzenbach: "O processo de modificação exige moderação, auto-limitação, propostas que levem em consideração os interesses dos outros Estados e interpretações politicamente razoáveis, baseadas nas condições contemporâneas" 7

Em conclusão, verifica-se que o costume, para ser aceito como tal, deve resultar da adoção necessária de um comportamento, reiterando-se este por longo tempo até que se consubstancie uma regra clara e tradicional. Atingido esse ponto e desde que reunidos todos esses elementos, emerge naturalmente o elemento psicológico, que é a aceitação da obediência a tal comportamento, pelos demais Estados, com o sentido de cumprimento de um dever internacional.

\section{b) Os Atos Unilaterais.}

7. Um problema de grande importância para o Direito Internacional e que tem suscitado múltiplas controvérsias é o da validade dos atos unilaterais, por meio dos quais os Estados pretendem alterar normas escritas ou costumeiras.

Alguns autores se opõem radicalmente ao acolhimento desses atos, sobretudo por considerarem que a criação de direitos é função da vontade coletiva, não da vontade individual. Esse é o caso, por exemplo, de BiscotTINI, sendo interessante notar, entretanto, que ele próprio reconhece que após a segunda guerra mundial estabeleceu-se nova praxe, admitindo que à vontade unilateral de um Estado ou de um grupo de Estados se atribua idoneidade para por normas válidas para todos. Em defesa de seu ponto de vista e procurando demonstrar que sua posição não é desprovida de realismo, esclarece Biscotrini que sua intenção não é contestar que um princípio reconhecido e afirmado num tratado internacional possa impor-se a sujeitos que permaneceram alheios ao ato. Mas acrescenta que desde que isso não possa ser explicado pela suposição de que o tratado tenha apenas codificado um costume preexistente, ou tenha ocasionado a produção de um costume novo, ainda se deve lembrar que

7. MORTON A. KAPLAN e NICHOLAS DE B. KATZENBACH, op. cit., págs. 250 e seguintes. 
tratados e costumes em sentido estrito não exaurem as fontes do Direito Internacional. Com isso quer dizer que, muitas vezes, o ato é apenas aparentemente unilateral, sendo, na verdade, baseado em fonte consagrada, à qual todos os Estados dão acatamento 8 .

No extremo oposto encontra-se, entre outros, GeORge SCELle, que chega mesmo a admitir o que denomina "tratado unilateral", que seria como que um tratado "por adesão". Sustenta ele que existe de fato, nas diversas sociedades internacionais, um corpo legislativo interestatal ainda invertebrado, não institucionalizado pela ordem jurídica internacional mas funcionando efetivamente. Esse poder legislativo é exercido através de atos unilaterais, mas estes, na realidade, não expressam apenas a vontade do Estado que os pratica 9 Vê-se, porém, que essa concepção pressupõe a concordância geral com o ato praticado por um determinado Estado, o que não resolve o problema dos atos unilaterais que não contarem com a aceitação dos demais Estados.

8. Relativamente aos atos propriamente unilaterais, praticados por um Estado sem nenhuma preocupação com a vontade dos demais, e até mesmo contra os interesses de um ou de muitos Estados, verifica-se, como já foi observado por Biscotrini, que tais atos vêm ocorrendo com frequência cada vez maior nos últimos anos.

Um fato de extraordinária importância, que encorajou essa prática e contribuiu para tornar menos incisiva a contestação de sua validade, foram duas proclamações feitas pelos Estados Unidos da América em setembro de 1945, enunciando uma orientação que passou a ser denominada "doutrina Truman". A primeira dessas proclamações continha a afirmação de "jurisdição exclusiva" sobre os recursos da plataforma continental, embora contivesse a ressalva de que essa jurisdição não afetava 0 alto mar das águas situadas sobre a plataforma. A segunda proclamação, complementar da primeira, declarava que, embora a jurisdição exclusiva não afetasse o alto mar, a pesca nesse alto mar sobre a plataforma continental passaria a ter um regime especial: ficaria sob jurisdição e controle exclusivos dos Estados Unidos onde só operassem, habitualmente, pes-

8. GIUSEPPE BISCOTTINI, Contributo alla Teoria degli Atti Unilaterali nel Diritto Internazionale, Milão, Ed. Giuffré, 1951, págs. 177 e seguintes.

9. GEORGES SCELLE, op. cit., págs. 600 e seguintes. 
queiros norte-americanos, permanecendo sob jurisdição e controle conjuntos dos Estados Unidos e de outro Estado, quando os pesqueiros deste último já operassem tradicionalmente naquelas águas.

Ora, em face da força política e militar dos norte-americanos e, ainda mais, por serem os Estados Unidos tradicionais defensores da livre empresa e da liberdade dos mares, as proclamações do Presidente Truman não sofreram contestação, passando a ser, pelo contrário, amplamente exploradas pelos Estados que também desejavam aumentar o âmbito de sua jurisdição e que só não o haviam feito temendo represálias dos mais poderosos. Sucederam-se, em curto prazo, inúmeras proclamações semelhantes à norte-americana, especialmente nas regiões em que os Estados tinham interesse em assegurar exclusividade para a extração de petróleo na plataforma continental.

Mais recentemente, havendo-se acentuado as possibilidades de exploração econômica do próprio mar, têm sido frequentes os atos unilaterais, proclamando a ampliação da jurisdição dos Estados sobre o mar contíguo, invocando-se quase sempre o precedente norte-americano para sustentação da validade dos atos unilaterais. Assim por exemplo, falando sobre a extensão do mar territorial por meio de atos unilaterais ponderou VICENTE RÁo: o direito internacional não desconhece o valor dos atos unilaterais declaratórios do direito, jamais tendo sido contestado o ato dos Estados Unidos que, unilateralmente, estenderam seu mar territorial das antigas tres milhas para seis milhas e mais seis milhas para fins fiscais. Acrescentou VicEnte Ráo que a declaração norte-americana sobre os direitos da plataforma continental, firmada por TRUMAN em 1945, foi ato unilateral não contestado por qualquer Estado. E procurando fixar princípios doutrinários para a validade dos atos unilaterais, pelo menos no tocante ao mar, aduziu: "o Estado ribeirinho tem o direito de fixar, soberanamente, os limites do mar territorial, considerando a necessidade de alimentação do povo, bem como o valor dos produtos que o subsolo do mar pode nos proporcionar. Portanto, os países latino-americanos, exercendo esse direito soberano, estão em situação de legítima defesa de seus direitos de sobrevivência e desenvolvimento" 10

10. Essas idéias de VICENTE RAO, externadas quando presidente da Comissão Jurídica Interamericana, estão fixadas numa entrevista publicada pelo jornal "O Estado de São Paulo", em 26 de fevereiro de 1972, pág. 9. 
9. O que se pode concluir em relação aos atos unilaterais é que existe ainda uma grande incerteza na prática e na doutrina. Não se afasta de maneira absoluta a possibilidade de que eles tenham validade jurídica. Ao mesmo tempo, reconhecendo-se a existência de grande perigo em sua aceitação irrestrita, procura-se encontrar um fundamento para justificar sua validade e, ao mesmo tempo, estabelecer as condições e os limites dessa validade. Evidentemente, para o Direito Internacional é inaceitável como fundamento a mera possibilidade "de fato" de fazer prevalecer uma vontade, sendo necessária uma base condizente com os interesses de toda a humanidade.

\section{c. Precedentes Relativos à Fixação da Extensão do Mar Territorial.}

10. A primeira observação importante a ser feita, quanto aos precedentes relativos à fixação da extensão do mar territorial, é que até hoje não se conseguiu um acordo multilateral, incluindo grande número de Estados, que fixasse uma regra de aceitação geral. Diversas orientações se sucederam através dos séculos, sempre com base no costume, sendo raros, até o século XIX, os tratados que contrariaram as normas costumeiras. É oportuno lembrar que, até então, o mar territorial foi apreciado quase que exclusivamente sob o ângulo da segurança, sendo poucos os Estados que usavam intensamente o mar, não havendo ensejo para grande número de conflitos.

No mundo contemporâneo, como já foi assinalado, uma série de fatores vem determinando a substituição das normas costumeiras por preceitos escritos, sendo, porisso, de maior interesse verificar como tem surgido estes últimos, no tocante ao mar territorial.

Três são os meios pelos quais os Estados tem promovido a alteração da extensão de seu respectivo mar territorial:

a) uma orientação, bem exemplificada pela atitude do México desde meados do século XIX, consiste no estabelecimento da medida do mar territorial em inúmeros acordos bilaterais. No ano de 1848 o México celebrou um tratado com os Estados Unidos da América, pelo qual ficou reconhecido um mar territorial de nove milhas como extensão do territó- 
rio mexicano. Depois disso, inúmeros tratados semelhantes foram assinados pelo México, com outros Estados separadamente. Desse modo obtém-se o reconhecimento e acatamento formal e solene de determinada orientação, chegando-se ao acolhimento praticamente geral, por via de atos bilaterais.

b) outra orientação, muito intensificada nos últimos anos, é a declaração unilateral de uma nova extensão do mar territorial, geralmente por meio de um ato legislativo interno. Os Estados que assim procedem, procuram, depois, consolidar sua nova posição através de tratados, mas quando estes são celebrados a atitude unilateral já está consumada.

c) uma terceira orientação, que foi adotada pelos países nórdicos no fim do século XVIII, consiste na celebração de um acôrdo multilateral, entre os Estados de determinada região. Em 1779 a Suécia, a Noruega e a Finlândia decidiram, num ato conjunto, fixar em quatro milhas os respectivos mares territoriais. Nesse caso as normas escritas não contrariam, propriamente, as costumeiras, pois a justificativa para aquela medida foi a alegação de que estavam apenas consolidando um "costume regional" Seguindo essa orientação outros grupos de Estados poderiam sustentar suas posições, com maior possibilidade de acatamento de suas decisões do que se agissem isoladamente. Apesar disso, porém, o fenômeno da invocação do costume regional não se repetiu em relação ao mar territorial.

11. O que se verifica por esses precedentes é que, em última análise, a fixação da extensão do mar territorial tem se apoiado na posição isolada de cada Estado, pois mesmo quando ela ocorre por meio de um tratado é fruto de uma reivindicação que não leva em conta os interesses do conjunto dos Estados. Vê-se também que é possível forçar a formação de um costume, especialmente de um costume regional. Desde que um grupo de Estados de certa região adote a mesma orientação e consiga mantê-la por tempo mais ou menos prolongado, poderá depois valer-sc das circunstâncias de fato para sustentar como regra costumeira o que foi, de início, uma afronta ao costume. 
III. A AMPLIAÇÃO DO MAR TERRITORIAL E SUAS CONSEQUENCIAS JURIDICAS.

a) Ampliação do Território.

12. Como já foi referido, é pacífico na doutrina, na jurisprudência e na prática internacional que o mar territorial é a parte do território do Estado que avança pelo mar. Por tal motivo, todas as normas relativas ao território têm aplicação ao mar territorial, não havendo qualquer distinção, do ponto de vista jurídico, entre a parte terrestre e a parte marítima do território de um Estado.

Dessa maneira, quando ocorre a ampliação do mar territorial de um Estado isso quer dizer que o próprio território desse Estado é que foi aumentado. Embora no mundo contemporâneo a extensão do território não tenha a mesma importância que teve até as primeiras décadas do século XX, para o prestígio dos Estados, continua sendo um fator relevante, sobretudo quando a maior extensão significar um aumento do potencial econômico. Ora, no caso do mar territorial é certo que qualquer ampliação é benéfica, pois significa sempre um acréscimo de território economicamente vantajoso, às vezes mesmo muito vantajoso.

Assim, pois, quando um Estado amplia unilateralmente seu mar territorial está promovendo um acréscimo de seu território, tornando-se mais rico e, em certo sentido, mais poderoso.

\section{b) Ampliação da Soberania.}

13. A moderna Teoria do Estado assinala que o território exerce duplo efeito: é a base física do Estado e, ao mesmo tempo, o elemento que indica os limites espaciais da soberania do Estado.

Dessa forma, aumentado o território, por via da ampliação do mar territorial, ampliam-se os limites dentro dos quais a vontade do Estado é Soberana. Isto quer dizer que dentro desse. âmbito todas as demais vontades, mesmo as dos outros Estados, ficam em plano inferior. Este dado é muito importante, pois atuando com soberania o Estado poderá decidir até mesmo sobre o acatamento ou não dos preceitos de Direito Internacional. No estágio atual deste ramo do Direito, sem que haja um órgão 
superior de coerção que assegure a eficácia das normas, a soberania tem praticamente o sentido de poder irrestrito. Assim, por exemplo, se um Estado obtém o reconhecimento de um mar territorial mais amplo adquire o direito de estabelecer todas as normas relativas ao uso dessa extensão de mar. E se tais regras forem demasiado restritivas para os demais, caberá a estes tentar, pelas vias jurídicas disponíveis, obter um tratamento mais favorável. E se o Estado a que pertencer o mar territorial permanecer irredutível em sua posição, desrespeitando até mesmo uma decisão da Corte Internacional, ainda assim partirá sempre de uma posição mais favorável, desde que alegue estar defendendo sua soberania. Esta possibilidade é que levou Clóvrs Bevilaqua a condenar a soberania como expressão do "egoismo dos Estados"

Por aí se vê que a ampliação dos limites espaciais da soberania pode ter consequências muito graves, uma vez que no âmbito de sua soberania o Estado é livre para sobrepor seus interesses aos dos demais, sem considerações de justiça ou injustiça.

\section{c) Conflitos com Direitos de Outros Estados.}

14. Como é evidente, a ampliação do mar territorial traz benefícios para o Estado que a promove, o que tem ocorrido, muitas vezes, por ato unilateral. A dúvida que logo surge é quanto à legitimidade dessa forma de obter benefícios. E para que se julgue esse ponto é indispensável a verificação de uma questão prévia fundamental, ou seja, é necessário saber se aquela vantgem obtida por um Estado significa prejuízo para outro ou outros. Não se há de dizer que a ocorrência ou não de prejuízo de terceiros é um critério absoluto para a aferição da legitimidade, pois muitas vezes aquele que sofre o prejuízo goza de privilégios injustos e ao ser prejudicado fica mais próximo de uma situação de justiça. De qualquer forma, porém, a verificação da ocorrência de prejuízo é um primeiro passo indispensável, para a posterior consideração de outros aspectos.

15. Duas são as situações que se podem apresentar quando um Estado amplia seu mar territorial; ou ele atinge o território de outro Estado, ou ele incorpora ao seu território uma parcela do alto mar. 
A primeira dessas hipóteses - o avanço sobre território de outro Estado - não deixa dúvidas quanto à antijuridicidade. Com efeito, se todos os Estados são igualmente soberanos em seus respectivos territórios, aquele que ampliando seu mar territorial atinge território alheio, seja terrestre ou marítimo, está ofendendo a soberania deste último. De fato, uma das características da soberania é que ela expressa um poder exclusivo, não admitindo superposições. Não há portanto, como aceitar, em termos jurídicos, que um Estado pretenda ter soberania onde outro já exerce poder soberano. Todavia, apesar da flagrante ilegitimidade dessa hipótese de amplição do mar territorial, ela tem ocorrido e pode ocorrer muitas vezes, quando dois Estados estão separados apenas por um estreito ou quando entre um e outro litoral não há grande distância.

16. A segunda hipótese, isto é, a ampliação do mar territorial no sentido do alto mar, exige um esclarecimento preliminar relativo à situação jurídica do mar alto, situado além das águas territoriais de qualquer Estado.

Desde o século XVII, quando foram dados os primeiros passos para a criação do Direito Internacional, a situação jurídica do mar e sua utilização preocuparam os estudiosos. Surge então com Hugo Grócio, no ano de 1604, a defesa do "mare liberum" Como se sabe, a obra de Grócro reflete, em grande parte, sua preocupação pela defesa dos interesses da Holanda, o que se dá com grande evidência no tocante aos mares. Sustentando a tese do mar livre, ou seja, negando que qualquer Estado possa assenhorear-se de alguma parte do oceano, Grócio procura demonstrar a legitimidade do comércio da Holanda com as Indias, contra os interesses de Portugal que, apoiado pelo PAPA, pretendia o monopólio daquele comércio. Em oposição à tese de Grócıo, o inglês JoHN SELDEN publicou em 1635 a obra Mare Clausum, procurando demonstrar a legitimidade do domínio das grandes potências marítimas sobre determinadas partes do oceano. E a história nos mostra que até o século XIX ainda perdurou a predominância de grandes potências sobre certas regiões oceânicas. Só então, em grande parte graças aos princípios econômicos do liberalismo, mas também, em boa parte, graças ao interesse da Inglaterra em expandir sua navegação e à sua possibilidade de enfrentar com êxito os opositores, consagrou-se a doutrina da liberdade dos mares. Ficou então estabelecido que nenhum Estado pode declarar-se dono do alto mar e restringir por qualquer forma a liberdade de navegação. 
Paralelamente ao desenvolvimento dessa doutrina, foi sendo estabelecida uma consciência que se poderia denominar "de interesse coletivo" em relação aos mares e sua utilização. Num primeiro momento, com a preocupação de obstar as pretenções dos Estados que se declaravam senhores de alguma parte do oceano, estabeleceu-se a noção do alto mar como res nullius, o que, entretanto, era inconveniente sob muitos aspéctos, pois a rejeição dos senhorios nesses termos continha em si a afirmação de que ninguém era competente para fixar regras sobre o uso do mar e garantir a liberdade de navegação. Evoluiu-se, então, para a concepção do mar como res communis omnium, muito mais adequada aos interesses gerais, pois sendo pertencente a todos os Estados isto significa que a utilização deve levar em conta os interesses de todos e, além disso, qualquer um é parte legítima para reprimir eventuais abusos.

Essas novas concepções do alto mar levaram à conclusão, consagrada em inúmeros tratados e convenções, de que o alto mar é insuscetível de apropriação por qualquer Estado ou grupo de Estados, devendo nele ser preservada a liberdade de navegação, bem como devendo ser evitada qualquer prática implicando uso exclusivo em detrimento dos demais Estados. Como decorrência inevitável, tem-se que a ampliação do mar territorial mediante o avanço no sentido do alto mar afeta os interesses de todos os Estados, afrontando um costume que já está consolidado em normas escritas. Essa ampliação, com efeito, coloca sob o domínio exclusivo de certo Estado uma parte daquilo que é considerado como havido em comum por todos. É bem verdade que o interesse fundamental, inspirador da doutrina da liberdade dos mares, é assegurar o livre trânsito, o que estará preservado se o ato de ampliação do mar territorial assegurar, a todos os demais Estados, o direito de passagem. Todavia, o direito à livre navegação é o principal interesse dos Estados sobre o alto mar, mas isso não quer dizer que seja o único. Desde que haja a possibilidade de obtenção de riqueza nessa parte comum é razoável pretender, em princípio, que tal riqueza seja explorada em comum.

Entretanto, assim como essas concepções sobre o alto mar evoluíram em curto prazo, chegando até à noção de res communis ommium, é razoável admitir-se que a evolução continui, chegando-se a novos conceitos que justifiquem uma utilização diferente, pelos menos de partes do mar alto. Nem se deve afastar a hipótese de que um conflito entre os conceitos de mar territorial e de alto mar determine uma revisão deles, para se encontrar um ponto de conciliação. 


\section{a) Variações da Extensão do Mar Territorial.}

17 A primeira manifestação governamental brasileira fazendo referência ao mar territorial foi a Circular n. ${ }^{\circ}$ 92, de 31 de jullho de 1850, dirigida pelo Ministério da Guerra aos Presidentes das Províncias marítimas. Recomendando vigilância sobre o litoral, a Circular recomendava que fossem advertidos os que, em condições irregulares, pretendessem aprisionar embarcações brasileiras que se achassem no mar territorial, protegido pelas baterias. Na opinião de MAROTTA RANGel isso mostra, claramente, que a proteção das baterias é que indicava a extensão do mar territorial, indo este até o ponto alcançado pelos tiros dos canhões 11 Esse, aliás, foi o primeiro critério adotado pelo Estado moderno. Já em 1610 , e nos anos subsequentes, em face de conflitos entre a Holanda e a Inglaterra, quando esta, sob o reinado de JAIME I, procurava ampliar cada vez mais seu domínio sobre os mares, sustentou Grócio que o Direito das Gentes limitava as pretensões de um príncipe sobre o mar, até onde tal príncipe pudesse impor sua vontade por meio de canhões. No começo do século XVIII coube a outro holandes, CoRNELIUS VAN BYNKERSHOEK, desenvolver a mesma tese em obras doutrinárias, conseguindo grande número de seguidores e, o que foi mais importante, a adesão de inúmeros Estados, fixando-se "o alcance da força das armas" como critério geralmente aceito. Foi com base nessa regra que começaram a surgir, nos tratados e documentos oficiais, as referências ao mar territorial com a amplitude de tres milhas, um vez que, até o fim do século XIX, era esse o alcance dos canhões mais poderosos. Ao mesmo tempo em que se abandonava o critério da "força das armas", foi surgindo uma variação, pois, embora a maioria dos Estados acolhesse as três milhas, alguns estabeleceram distância diversa. Note-se que a essa altura o costume havia consagrado o mar territorial equivalente ao alcance dos canhões. No momento em que essa norma começou a ser substituída não havia ainda outra, pois a distância de três milhas necessitaria de algum tempo para obter a consagração de novo costume, como acabaria acontecedendo.

11. VICENTE MAROTTA RANGEL, Regulamentação do Mar Territorial Brasileiro, in Problemas Brasileiros n. 92, abril, 1971, págs. 5 e seguintes. 
Acompanhando a maioria dos Estados, o Brasil adotou a medida de três milhas, tendo-o feito, entretanto, quando já estava definitivamente aceita esta regra como costume internacional. Essa decisão brasileira foi externada na Circular n..$^{\circ}$ 43, de 25 de agosto de 1914, do Ministério das Relações Exteriores. No ano de 1934, quando foi aprovado o Código de Pesca (decreto n. ${ }^{\circ} 23672$, de 2 de janeiro de 1934), o Brasil adotou uma inovação importante, declarando sua primazia numa zona contígua ao continente, até doze milhas da costa, inclusive em matéria de pesca. Mas o mar territorial continuou a ser de três milhas.

A partir de 1966 a Brasil passaria, em curto período de tempo, por várias etapas no sentido da ampliação de seu mar territorial. Com efeito, em 18 de novembro desse ano foi aprovado o decreto-lei n. 44 , ampliando para seis milhas a extensão do mar territorial. Tornando mais específica a fixação da zona contígua de doze milhas, já declarada anteriormente, o mesmo decreto-lei $n .^{\circ} 44$ estabeleceu que, a partir do limite externo das águas territoriais, o Brasil teria o seguinte: a) uma zona contígua de seis milhas, com jurisdição no concernente à prevenção e à repressão das infrações da lei brasileira em matéria de polícia aduaneira, fiscal, sanitária e de imigração; b) uma zona de seis milhas, coincidindo portanto com a anterior, na qual the caberiam os mesmos direitos exclusivos de pesca, de jurisdição em matéria de pesca, e de exploração dos recursos vivos do mar, que the cabem em seu mar territorial.

Pouco tempo depois, em 25 de abril de 1969, o decreto-lei n.o 553 elevaria para doze milhas o mar territorial, incluindo-se neste, a partir de então, a zona contígua e a zona de pesca referidas no decreto-lei anterior. Desde então, para todos os efeitos, o Brasil se considerava soberano numa faixa de mar da largura de doze milhas, "medidas a partir da linha de baixa mar".

Menos de um ano depois, ou seja, em 25 de março de 1970, por meio do decreto-lei n. $^{\circ} 1098$, o Brasil ampliou consideravelmente seu mar territorial, fixando-o em duzentas milhas "a partir da linha de baixa-mar do litoral continental e insular brasileiro" Para não dar margem a qualquer dúvida, o decreto-lei tornou expresso no artigo $2 .^{\circ}$, que "a soberania do Brasil se estende ao espaço aéreo acima do mar territorial, bem como ao leito e sub-solo deste mar" $\mathrm{O}$ artigo $4 .^{\circ}$ previu a possibilidade de que, dentro das duzentas milhas, fossem estabelecidas duas zonas de pesca: uma exclusiva para embarcações brasileiras e outra per- 
mitida a embarcações de outra bandeira, desde que estas sejam autorizadas pelo Brasil e respeitem a regulamentação brasileira. $\mathrm{O}$ decreto $\mathbf{n}^{\mathbf{0}}$ 68.459 , de $1 .^{\circ}$ de abril de 1971 , estabeleceu essa regulamentação, fixando, como regra geral, que nas primeiras cem milhas, a partir da costa brasileira, somente poderão exercer atividades de pesca entidades brasileiras. Nas restantes cem milhas permite-se a atividade de pesqueiros de outras nacionalidades, exigindo-se, entretanto, que sejam autorizados pelo Brasil e se sujeitem às obrigações e limitações impostas na legislação brasileira, inclusive o pagamento de taxas. Entretanto, o mesmo decreto amplia as possibilidades de participação estrangeira nas atividades de pesca dentro do mar territorial, permitindo que, em circunstâncias especiais, seja autorizada essa atividade a estrangeiros também no âmbito das primeiras cem milhas.

18. Um ponto de grande importância que deve ser ressaltado está contido no artigo $3 .^{\circ}$ do decreto-lei n. $^{\circ} 1098$, que ampliou o mar territorial para duzentas milhas. Diz o citado artigo 3..$^{\circ}$ " $E$ reconhecido aos navios de todas as nacionalidades o direito de passagem inocente no mar territorial brasileiro" Por meio de três parágrafos acrescentados ao artigo fica esclarecido que por "passagem inocente" se compreende o simples trânsito, sem qualquer atividade estranha à navegação e sem efetuar paradas, a não ser por incidentes da própria navegação. Além disso, reafirma-se a soberania brasileira mediante a advertência de que tal passagem não exclui o dever de obediência aos regulamentos brasileiros, previstos como necessários para garantir a paz, a boa ordem e a segurança, bem como para evitar a poluição das águas e o dano aos recursos do mar.

\section{b) Formas de Alteração da Extensão.}

19. Examinando-se os instrumentos utilizados pelo Brasil para fixar ou ampliar seu mar territorial, verifica-se que tais medidas foram sempre adotadas por meio de atos unilaterais e não pela subscrição de acordos multilaterais.

Há, todavia, um elemento diferenciador entre as várias posições adotadas pelo Brasil, através do qual se podem identificar duas significações diferentes para os atos unilaterais. Quando fixou a extensão do 
mar territorial em relação com a proteção das baterias, bem como ao estabelecer a medida exata de três milhas, o Estado brasileiro valeu-se de atos unilaterais, mas agiu em conformidade com o costume internacional já reconhecido pela generalidade dos Estados. Pode-se dizer que o Brasil apenas formalizou, nessas oportunidades, sua adesão a regras já estabelecidas internacionalmente.

Bem diferente é o que ocorre a partir de 1966, quando o mar territorial brasileiro passa a seis milhas, para depois avançar até doze e, finalmente, duzentas milhas. Nestas ocasiões não ocorreu a simples conformação a normas de aceitação geral. Na verdade, em nenhuma dessas ocasiões o Brasil adotou posição original, que já não tivesse precedentes. Desde logo, entretanto, é preciso reconhecer que tais precedentes ainda não representavam um novo costume, regional ou geral. Mesmo em relação à extensão de duzentas milhas verifica-se que já havia diversos exemplos na América Latina, quando o Brasil decidiu adotá-la. O que se nota, porém, é que existia e ainda existe divergência entre os Estados latino-americanos, havendo diversos que são contrários a uma ampliação tão drástica do mar territorial, não se podendo, assim, falar na ocorrência de uma orientação uniforme e tradicional, que possa valer como um novo costume, ao qual o Estado brasileiro tenha, pura e simplesmente, aderido.

\section{c) Concordância e Conflito com Outros Estados.}

20. A decisão brasileira de ampliar o mar territorial para duzentas milhas desencadeou uma série de reações, algumas favoráveis, outras contrárias, sendo interessante notar que mesmo os opositores fizeram algumas concessões, que poderão dar ao Brasil uma situação mais favorável em futuras negociações.

Entre os que se manifestaram a favor da medida estão, como é evidente, os Estados que também optaram pela mesma orientação, antes ou depois do Estado brasileiro, encontrando-se entre eles inúmeros Estados latino-americanos, vários africanos e mesmo alguns europeus, ou por motivos de política econômica, como foi o caso da Espanha, ou por estarem interessados na ampliação de seu próprio mar territorial, como sucede com a Islândia. Houve também um pronunciamento favorável da 
República Popular da China, atitude essa que foi interpretada como de hostilidade aos Estados Unidos da América e à União Soviética, uma vez que ambos se sentiram prejudicados pela nova orientação brasileira.

As manifestações contrárias, por seu turno, são de duas espécies: alguns se opõem à expansão do mar territorial para duzentas milhas, embora admitindo a ampliação por ato unilateral e propondo mesmo que o Estado tenha controle, não soberania, sobre aquela extensão. Esta posição será analisada mais adiante. Outros adotam uma atitude de oposição mais radical, negando legitimidade à ampliação unilateral e sustentando que, mesmo por acordos multilaterais, nenhum Estado pode pretender soberania ou exclusividade sobre uma parte tão grande do oceano. E interessante assinalar, entretanto, que muitos destes opositores que se mostram mais radicais celebraram acordos com o Brasil para que seus respectivos barcos pesqueiros pudessem operar na faixa que vai de cem a duzentas milhas da costa brasileira. Eis alguns dos principais acordos celebrados:

1. Em 4 de agosto de 1971 foi assinado um acordo com Trinidad-Tobago, sobre a pesca de camarões. Ficou expresso que as infrações à lei brasileira, ocorridas nas águas territoriais brasileiras, seriam punidas conforme a lei brasileira. Esse acordo foi o primeiro celebrado após a extensão do mar territorial para duzentas milhas. Nele não se faz menção ao problema, não havendo aceitação ou ressalvas, de maneira expressa.

2. No dia 19 de agosto de 1971 o Brasil e o Reino dos Países Baixos (Holanda, Surinã e Antilhas Holandesas) assinaram acordo sobre a pesca do camarão em águas brasileiras, entre cem e duzentas milhas da costa, por barcos do Surinã. Considerando o acordo apenas provisório, os holandeses declararam que ele não implicava o reconhecimento do mar territorial brasileiro, nem um compromisso perante qualquer posição jurídica internacional relativa à extensão das águas territoriais. De qualquer forma, porém, a simples existencia do acordo já representava, apesar da ressalva, uma submissão à determinação brasileira, embora em caráter não-permanente.

3. Um acordo de grande importância - sem dúvida, o mais importante dos que foram assinados até agora - foi celebrado com os Estados Unidos da América em 9 de maio de 1972, para ter vigência até $1 .^{\circ}$ de janeiro de 1974, visando a pesca do camarão. A importância do acordo 
reside tanto na influência exercida pelos Estados Unidos sobre o relacionamento de todos os Estados do mundo, quanto na circunstância de serem os norte-americanos os mais ardorosos opositores da extensão unilateral do mar territorial e de qualquer pretensão a exclusividade além de doze milhas.

Pelo mencionado acordo, os Estados Unidos obtiveram autorização do Brasil para a pesca nas cem milhas externas do mar territorial, submetendo-se à regulamentação brasileira, aceitando as limitações impostas por esta e, além disso, pagando as taxas estipuladas por mútuo entendimento. Em face da óbvia importância desse ajuste e das consequências que dele poderão decorrer, cada uma das partes procurou fixar a posição mais conveniente aos seus interesses, ficando evidente que, apesar da assinatura do acordo, as divergências fundamentais continuaram existindo. Assim é que no preâmbulo ficou expresso o seguinte: "As partes deste acordo tomam nota da posição do governo da República Federativa do Brasil, que: Considera que seu mar territorial se estende a uma distância de duzentas milhas náuticas, a partir da costa brasileira" E mais adiante: "Tomam nota, também, da posição do governo dos Estados Unidos, que: "Não se considera obrigado, conforme o Direito Internacional, a reconhecer reivindicações de mar territorial com mais de três milhas náuticas, nem jurisdição de pesca além de doze milhas náuticas, zona de jurisdição além da qual todas as nações têm o direito de pescar livremente".

A ressalva norte-americana foi muito clara, embora em contradição com atitudes e fatos que permitem sustentar que os Estados Unidos da América também se assenhorearam de extensão de mar superior a doze milhas, por ato unilateral e para satisfação de seus interesses exclusivos. De fato, bastaria lembrar as proclamações do Presidente Truman, já anteriormente referidas neste trabalho, para demonstrar que também o Estado norte-americano procede a alterações unilaterais de grande alcance, quando isto é conveniente aos seus interesses. Além disso, porém, é oportuno assinalar que vários Estados componentes da federação norteamericana estenderam seu respectivo mar territorial para duzentas milhas, sem que até agora tenham sido julgadas inconstitucionais essa medidas, o que significa que elas obrigam o próprio governo norte-americano. $O$ último dos Estados a tomar essa atitude foi o Massachussets, que por uma lei estadual de 29 de novembro de 1971 ampliou seu mar ter- 
ritorial para duzentas milhas, alegando a necessidade de proteger os interesses de seus pescadores e de suas empresas de pesca, em face da concorrência dos pesqueiros soviéticos.

21. Quando noticiou a celebração do acordo do camarão entre o Brasil e os Estados Unidos da América, o jornal "O Estado de São Paulo" procurou acentuar a importância do fato, considerando-a uma vitória diplomática brasileira.

Para confirmar essa conclusão, assinalou, com rara felicidade, seis pontos essenciais que favorecem a posição brasileira, apesar de todos os cuidados e de todas as ressalvas constantes do acordo por exigência norte-americana. São os seguintes esses pontos:

"1. O Brasil pode exercer controle na área delimitada para a pesca de camarão, em águas situadas dentro das duzentas milhas;

2. Os Estados Unidos têm, nas águas brasileiras, uma zona limitada para pescar camarão;

3. O Brasil pode cobrar taxas de compensação em relação à pesca efetuada em águas brasileiras;

4. O governo norte-mericano é obrigado a registrar os pesqueiros que operarão em águas que o Brasil reivindica como suas, e o Brasil pode vetar os barcos que não tenham cumprido uma série de formalidades e não atendam aos requisitos estabelecidos;

5 Há um limite para o número de barcos americanos, mas não há para os barcos brasileiros;

6. Ao Brasil compete a inteira fiscalização da zona delimitada" ${ }^{12}$.

22. Como se pode verificar, as reações suscitadas pela atitude brasileira foram várias, indo desde o apoio irrestrito à mais absoluta oposição, com inúmeras posições que podem ser consideradas intermediárias.

As opiniões favoráveis, mesmo que apenas parcialmente favoráveis, deverão auxiliar a sustentação da tese brasileira e revelam os prováveis aliados do Brasil na defesa de sua iniciativa. As posições contrárias, por

12. "O Estado de São Paulo", edição de 10 de maio de 1972, pág. 16. 
sua vez, deverão influir negativamente, como é óbvio. Mas é importante assinalar que nenhuma delas deixou de sugerir a possibilidade de algumas concessões, que representarão uma vantagem em relação à situação anterior à extensão para duzentas milhas. Assim, pois, mesmo que o Brasil não obtenha êxito na sustentação integral de sua tese, é razoável prever-se que algum progresso será conseguido, havendo uma contribuição brasileira para uma disciplina geral, e mais justa, dos direitos sobre o mar.

\section{PERSPECTIVAS A CURTO E A LONGO PRAZO.}

23. O exame de tudo o que vem ocorrendo ultimamente, em relação ao problema do mar territorial, demonstra que foram seriamente abaladas as posições tradicionais, tendo surgido uma série de elementos novos, sem que se possa ainda identificar as inovações que deverão durar. Com efeito, desde a segunda guerra mundial vêm ocorrendo conflitos, mais frequentes nos últimos anos, envolvendo o problema da extensão e do uso do mar territorial. Verifica-se também que, apesar de ocorrerem esses conflitos em várias partes do mundo, é na América Latina que se localiza atualmente o ponto crucial dos debates, sobretudo pela circunstância de haver um bloco de Estados, sustentando posições semelhantes e situados na mesma área geográfica.

A amplitude dos interesses afetados pelo problema fez com que a própria ONU interferisse tentando encontrar soluções que satisfizessem a generalidade dos Estados. Com esse intuito, ou seja, visando solucionar o problema do mar territorial e outros ligados ao uso do mar, é que foram realizadas em Genebra, nos anos de 1958 e 1960, duas Conferências dedicadas ao Direito do Mar. Ambas, entretanto, deixaram em aberto as questões relativas à extensão do mar territorial e à competência para fixá-la. Nova conferência deveria realizar-se no início de 1973, tendo sido adiada, porém, em face da extrema complexidade do problema, esperando-se que os Estados consigam reduzir os pontos de conflito, antes da reunião geral. A última decisão foi no sentido da realização de sessões preliminares em Nova York, nos meses de novembro e dezembro de 1973, devendo ser realizadas as principais sessões da conferência em Santiago do Chile, em abril e maio de 1974. 
O que se pode assinalar, desde já, é que serão bem grandes as dificuldades. Uma comprovação disso é a posição adotada pelos Estados latino-americanos, ao se reunirem visando fornecer subsídios à Conferência da ONU. Depois de haver debatido a matéria em vários encontros, proclamando alguns princípios gerais, a Comissão Jurídica Interamericana se reuniu em setembro de 1971 e aprovou algumas normas mais específicas, destinadas a informar uma futura declaração dos Estados membros da Comissão, sobre o Direito do Mar. Ficou, então, estabelecido que essa declaração deveria incluir, entre outros, os seguintes princípios:

“a) o direito dos Estados ribeirinhos, em virtude de sua soberania sobre os recursos naturais dos espaços marítimos adjacentes, de dispor deles para seu pleno aproveitamento em função do desenvolvimento econômico, social e cultural dos povos;

b) o direito dos Estados ribeirinhos, em defesa dos interesses de suas populações e conforme o Direito Internacional, de estabelecer as zonas sobre as quais exercem sua soberania ou jurisdição marítima, de acordo com critérios razoáveis e atendendo às suas características geográficas e ecológicas, assim como as exigências do aproveitamento de seus recursos, sem afetar o princípio da liberdade de comunicação internacional".

Voltando a reunir-se, em fevereiro de 1973, a Comissão Jurídica Interamericana teve que superar uma série de divergências internas para chegar a um projeto de tratado sobre o Direito do Mar, verificando-se afinal que, embora ocorresse a aprovação unânime do projeto, inúmeros signatários, entre eles o representante dos Estados Unidos, foram vencidos em suas posições, podendo reabrir o debate quando o assunto vier a ser considerado na Conferência convocada pela ONU para 1974. O principal ponto de divergência entre os membros da Comissão consistiu na aceitação das duzentas milhas como mar territorial, sujeito à soberania dos respectivos Estados, havendo uma forte corrente que prefere estabelecer apenas a jurisdição dos Estados sobre aquela extensão, reservando uma faixa bem menor para o mar territorial.

De qualquer maneira, porém, não se pode negar importância ao projeto da Comissão Jurídica Interamericana, especialmente porque se vai procurar apresentá-lo como reflexo do pensamento comum latino-americano, havendo notícia de que também Cuba foi consultada para subscrevê-lo. São as seguintes as principais conclusões fixadas no projeto: 
1. ${ }^{\text {a) E }}$ reconhecida a soberania ou jurisdição dos Estados, para estabelecer a extensão de seu mar numa área de duzentas milhas.

2. ${ }^{\text {) }) ~ D u a s ~ z o n a s ~ s a ̃ o ~ r e c o n h e c i d a s ~ d e n t r o ~ d e s s a s ~ d u z e n t a s ~ m i l h a s . ~}$

a) uma faixa de doze milhas, adjacente ao litoral, na qual a navegação se fará sob o regime de passagem inocente;

b) uma faixa de cento e oitenta e oito milhas, na qual haverá liberdade de navegação. Nesta zona será garantida também a liberdade de imersão de cabos e condutores submarinos e a utilização do espaço aéreo.

Quanto à exploração econômica, ficou estabelecido que os Estados costeiros têm o direito de explorar os recursos de sua plataforma continental, afirmando-se também que os fundos dos oceanos, além de duzentas milhas e da plataforma, são patrimônio da humanidade.

Como fica evidente, o projeto foi uma solução eclética, não refletindo, na realidade, a posição fundamental de qualquer dos signatários, ficando em aberto o problema da extensão do mar territorial. A primeira conclusão pode dar a impressão de que foi acolhida a tese das duzentas milhas, mas a leitura atenta demonstra que se recorreu a uma fórmula dúbia, que aprova essa extensão, deixando para discussão futura se ela deve ser limite da soberania ou da jurisdição.

24. Um resumo de tudo quanto se fez e se escreveu a respeito do problema permite-nos aponta três dados de grande importância, que deverão influir sobre os debates e sobre o comportamento dos Estados em relação ao mar territorial. Esses dados, a respeito dos quais teceremos agora algumas considerações, são os seguintes: a) a afirmação de novos conceitos; b) o reconhecimento da impossibilidade de soluções uniformes; c) maior disciplina jurídica.

\section{a. Afirmação de Novos Conceitos.}

25. Alguns conceitos tradicionais, como o de soberania e o de passagem inocente, continuam a ser utilizados. Mas, em face de novas realidades, outros vão ganhando consistência influindo sobre os primeiros e propondo-se até como alternativas. 
Uma inovação importante, que já penetrou no direito positivo e tende a ser cada vez mais aperfeiçoada e utilizada é a divisão do mar contíguo ao litoral em "zonas", de acordo com diferentes objetivos, podendo elas constituirem partes do mar territorial ou estarem situadas fora dele. Assim, por exemplo, já tem largo uso as designações de zona de pesca e zona de segurança, cujas extensões, todavia, ainda são extremamente variáveis, não havendo tmbém uma definição precisa dos direitos e dos poderes que se compreendem em cada zona. Ainda recentemente, em janeiro de 1973, quando a Comissão Jurídica Interamericana se reuniu para fixar a posição de seus integrantes quanto a alguns aspectos fundamentais do Direito do Mar, surgiu uma nova idéia, baseada na fixação de zonas. Rejeitando as noções de mar territorial e mar patrimonial, para regular o uso de amplas faixas do oceano para fins econômicos, o delegado de El Salvador propos o conceito de "zona econômica" Esta compreenderia uma faixa de doze milhas, na qual prevaleceriam os interesses de segurança e econômicos, do Estado costeiro. Além dessa extensão haveria outra faixa, que poderia ir até duzentas milhas, na qual o Estado costeiro poderia estabelecer uma regulamentação exclusivamente quanto a objetivos econômicos. Há, entretanto, inúmeros interesses dos Estados, ligados a controle aduaneiro, proteção sanitária, conservação de espécies, e muitos outros, além dos interesses econômicos, prevendo-se também em relação àqueles o estabelecimento de zonas, submetidas a regimes especiais. Essa conceituação de zonas, embora ainda imprecisa, já vem influindo sobre a noção de mar territorial, podendo-se prever uma influência cada vez mais acentuada.

26. Outro conceito de extraordinária importância, que vem competindo com o de mar territorial, é o de "mar patrimonial" Este conceito, na realidade, vem sendo insistentemente proposto como alternativa aceitável, para que os Estados costeiros protejam suas riquezas marítimas e tirem delas o maior benefício, sem excluir a presença dos demais Estados. Entre os que se opõem ao mar territorial de duzentas milhas muitos já manifestaram o propósito de aceitar essa extensão para o mar patrimonial.

Relativamente à significação precisa e ao alcance do conceito de mar patrimonial, o que existe até agora são opiniões e projetos sem uniformidade, só havendo unanimidade quanto à exclusão de poder soberano sobre essa faixa de mar. Ao que tudo indica, haverá muita insistên- 
cia para que prevaleça o mar patrimonial sobre o territorial, quando se tratar de uma extensão muito ampla. É provável que muitos Estados aceitem essa alternativa, procurando fazer, entretanto, com que no conceito de mar patrimonial se inclua a proteção de muitos outros interesses além dos econômicos.

27. Estreitamente ligada à alternativa mar territorial e mar patrimonial surge a idéia de uma opção entre soberania e jurisdição. $\mathrm{E}$ para reforçar a afirmativa de que a jurisdição sem soberania oferece proteção suficiente alguns utilizam a expressão "jurisdição exclusiva".

Um ponto que permanece obscuro, e que precisa ser esclarecido a fim de que se possa avaliar o verdadeiro alcance dessa opção, é de que modo será possível concretizar-se uma jurisdição exclusiva sem soberania. De fato, quando se atribui a um Estado a exclusividade de jurisdição isso quer dizer que fica afastado o poder de decisão dos demais Estados sobre a mesma área. E assim se estará conferindo ao titular da jurisdição exclusiva um poder que, na realidade, corresponde à soberania. A menos que se tome a expressão "jurisdição" num sentido restrito, como a simples possibilidade de estabelecer regulamentos e solucionar conflitos submetendo-se a normas oriundas de um poder superior, que deveria ser, no caso, o conjunto dos Estados. Só com tal sentido é que a jurisdição exclusiva confere poder de controle sem soberania, ou, em outras palavras, atribui poder de administração sem o poder de decisão em última instância. É matéria que também está à espera de melhor esclarecimento, como ocorre com outros conceitos propostos ou mesmo já em início de utilização, muitos dos quais poderão desempenhar um papel relevante no futuro Direito do Mar.

\section{b. Impossibilidade de Extensões Uniformes.}

28. Outro dado importante, na consideração dos problemas relacionados com o mar territorial, é o reconhecimento da impossibilidade de uma solução uniforme para todo o mundo, em face das novas possibilidades e necessidades que determinam o comportamento dos Estados.

Um primeiro fator que levou à diversidade de pontos de vista quanto à amplitude do mar territorial foi a alteração das possibilidades de ataque e defesa, afetando as necessidades de segurança. Com o aperfeiçoa- 
mento das armas e o aumento de seu alcance ficou superada a distância de três milhas como proteção suficiente. Entretanto, a diversidade das situações políticas dos Estados e do poderio bélico de cada um afetou de muitas maneiras diferentes os cuidados de segurança. Alguns Estados se sentiram mais visados ou mais vulneráveis e procuraram ampliar consideravelmente seu mar territorial para se protegerem melhor. Outros, num extremo oposto, ou não sentiram um crescimento das ameaças ou se reconheceram incapazes de uma defesa muito eficiente em face dos modernos meios de agressão, e não julgaram necessário alterar a extensão de seu mar territorial por motivos de segurança. Entre esses dois extremos encontra-se uma gama variada de preocupações e de possibilidades, ligadas à questão da segurança, determinando a maior ou menor ampliação do mar territorial.

Outro fator que vem exercendo considerável influência para que haja uma grande variedade de critérios, quanto à largura da faixa de mar territorial, é a multiplicação vertiginosa das possibilidades de aproveita, mento das riquezas do mar. Vale dizer, os Estados costeiros, de maneira geral, passaram a se preocupar com a largura do mar territorial por motivos econômicos. E neste caso os choques de interesses contribuem para tornar ainda mais heterogêneos os pontos de vista. Em primeiro lugar, é preciso ter em conta que os recursos econômicos não são sempre os mesmos, bastando lembrar a diferença entre a exploração de reservas petrolíferas submarinas e as múltiplas atividades ligadas à pesca. Além disso, verifica-se que mesmo estas últimas atividades implicam uma série de variações, segundo o lugar, a época do ano e o tipo de pescado. A par de todos esses fatores, já por si suficientes para impedir um tratamento uniforme de todos os mares, existe a oposição de interesses entre o Estado costeiro, em cujas vizinhanças se acham as riquezas, e os demais Estados que desejam explorá-las e estão muito mais aparelhados para fazê-lo. E compreensível que os primeiros desejem ampliar ao máximo o seu mar territorial, encontrando a oposição dos outros que desejam vê-lo reduzido ao mínimo. Daí uma série de conflitos e de posições intermediárias.

Ao lado disso tudo existem outras preocupações, como o controle aduaneiro, os cuidados sanitários, os inłeresses científicos, cada uma dessas atividades exigindo o controle sobre uma extensão diferente. E para tornar ainda mais evidente a impossibilidade de uma extensão uniforme, 
válida para o mundo todo, há o problema dos estreitos, vários deles de importância fundamental para a navegação, e, em alguns casos, para o intercâmbio de riquezas de alguns Estados.

29. Essa diversidade de interesses, de necessidades e de objetivos já determinou, na realidade, o aparecimento de inúmeros critérios na fixação do mar territorial. $O$ último desses critérios foi precisamente a extensão de duzentas milhas.

Examinando o problema com grande acuidade e procurando chegar a uma síntese das posições fundamentais, MAROTTA RANGel observa que "a análise das Conferências de Genebra nos leva a asseverar que o princípio dominante na matéria é o de que nenhum mar territorial pode ter largura inferior a três nem superior a doze milhas" 13. Para KaPLAN e KATZENBACH é possível uma conclusão ainda mais precisa, parecendo-lhes fora de dúvida que a tendência predominante é no sentido de se fixar em doze milhas a extensão do mar territorial, aumentando constantemente o número de Estados favoráveis a esse limite 14

O que fica muito evidente é que não existe uma orientação uniforme e que a diversidade não é determinada por meras preferências, mas, em lugar disso, decorre da grande variedade de situações e de objetivos. Reconhecendo a impossibilidade de uma solução única, válida para todo o mundo, Franco FloRio propõe a adoção de larguras diversas, oferecendo um certo número de opções 15

Dando ênfase ainda maior à necessidade de se admitir um critério flexível para a fixação do mar territorial, José LUIZ DE AsCÁRRAGA procurou elaborar uma fórmula, comportando diversas variáveis que lhe pareceram fundamentais. Essa fórmula matemática estabeleceria uma relação entre o mar territorial (M), a densidade da população mundial (DM), a densidade da população do Estado em questão (Dp), a área da plataforma continental desse mesmo Estado (Ap), e, finalmente, a extensão da linha de sua costa (C). Com esses dados seria composta a seguinte equação: $\frac{\mathrm{Dp}}{\mathrm{DM}} \times \frac{\mathrm{Ap}}{\mathrm{C}}=\mathrm{M}$

13. Cf. Natureza Juridica e Delimitação do Mar Territorial, pág. 235.

14. Ob. cit., pág. 163.

15. Il Mare, Territoriale e la sua Delimitazione, Milão, Ed. Giuffré, 1947, págs. 103 e seguintes. 
Não há dúvida de que essa fórmula oferece um critério flexível, determinando uma grande variação do mar territorial dos Estados ${ }^{16}$. Nota-se, entretanto, que ela atribui importância uniforme a fatores que, na realidade, influem de maneira diversa, razão pela qual adquire um caráter formalista e artificial, podendo levar a soluções inadequadas. De qualquer forma, entretanto, não deixa de ser uma importante contribuição, demonstrando a possibilidade e a conveniência de se raciocinar a partir da aceitação do mar territorial de extensões variáveis de lugar para lugar.

\section{c. Maior Disciplina Jurídica .}

30. O terceiro dado de grande importância, no debate que se trava atualmente a respeito do mar territorial, é a consciência generalizada de que a matéria deve ser resolvida em termos de Direito, não se recorrendo a soluções estritamente políticas, sempre favoráveis aos Estados mais poderosos.

Um exame atento do relacionamento entre os Estados no mundo contemporâneo revela que o poderio militar já não é suficiente para assegurar o predomínio da vontade dos mais fortes. Inúmeros acontecimentos, alguns de grande repercussão como a guerra do Vietnã, demonstram que também os pequenos Estados podem encontrar meios para opor sérios obstáculos às tentativas de solução pela força. Algumas vezes o Estado fraco e sem recursos bélicos obtém o auxílio de uma grande potência, mas em outros casos improvisa soluções, contando com seus próprios recursos e suportando grandes sacrifícios, para comprovar sua capacida. de de se manter independente e de promover a defesa eficiente de seus interesses. No tocante ao mar territorial tem-se verificado exatamente esta última hipótese, ou seja, Estados considerados pobres e militarmente fracos adotam atitudes intransigentes e agressivas, na defesa de posições que afirmam serem correspondentes a direitos seus. As grandes potências, por seu lado, embora manifestando uma intransigente recusa de aceitação daquelas posições procuram a negociação e o entendimento, valendo-se, sobretudo, de argumentos jurídicos e propondo soluções através de fórmulas jurídicas.

16. A fórmula de Ascárraga é reproduzida, sem manifestação de adesão ou recusa, na obra de MAROTTA RANGEL Natureza Jurídica e Delimitação do Mar Territorial, à pág. 227. 
Exemplo significativo desta última atitude é o comportamento norte-americano, em face das restrições impostas aos seus pesqueiros pelos Estados latino-americanos, inclusive o Brasil. Externando, inicialmente, a recusa pura e simples do admitir um mar territorial superior a três milhas, os norte-americanos evoluíram para uma nova posição, admitindo restrições às atividades de natureza econômica, em extensão que pode ser até muito ampla, acenando com a aceitação da ampliação do mar territorial até doze milhas náuticas. $O$ plano dos Estados Unidos, que, segundo fontes bem informadas e insuspeitas, deverá ser proposto à Conferência mundial de 1974, pode ser assim resumido quanto aos seus pontos principais:

a) será reconhecido a todos os Estados o direito de fixar a extensão de seu respectivo mar territorial, até o limite de doze milhas.

b) cada Estado terá o controle das riquezas do leito oceânico adjacente, até o limite de doze milhas marítimas ou até onde as águas não tiverem profundidade superior a seiscentos e cincoenta pés ${ }^{17}$, prevalescendo entre essas duas medidas a que for mais distante da costa.

c) no espaço além do limite dos direitos sobre o leito oceânico e sobre a plataforma continental, o governo local agirá como um administrador, autorizando e tributando operações submarinas, tais como mineração e perfuração. Uma certa quota dessas contribuições, talvez cincoenta por cento, seria distribuída entre os países subdesenvolvidos.

d) seria constituído um Tribunal Internacional para cuidar da aplicação dos direitos especiais da pesca 18

17. E oportuno esclarecer que a milha marítima ou náutica mede no Brasil $1852 \mathrm{~m}$, medindo $1853 \mathrm{~m}$ segundo a posição oficial dos Estados Unidos. O pé, unidade de medida de comprimento ainda em uso nos países anglo-saxônicos, vale doze polegadas, ou seja, 0,304.8 m. Assim sendo, as duzentas milhas equivalem a 370 quilômetros, mais ou menos, enquanto que os seiscentos e cincoenta pés correspondem, aproximadamente, a 218 metros de profundidade.

18. O plano dos Estados Unidos está inserido numa reportagem sobre os Direitos do Mar publicada pela revista norte-americana Time, edição de 16 de agosto de 1971, à página 29. Embora não seja uma fonte oficial, essa revista, de grande circulação internacional, é geralmente bem informada, devendo-se assinalar que sua reportagem não sofreu qualquer reparo ou desmentido. Contrariando esse plano, foi proposto à Câmara de Representantes dos Estados Unidos da América, no início de 1973, um projeto de lei subscrito por vinte e seis membros, ampliando para 
É evidente que tal plano pode ser combatido e rejeitado sob muitos aspectos. Assim, por exemplo, a distribuição de quotas a países subdesenvolvidos é absurdo inaceitável, pois, em primeiro lugar, haveria o problema de fixação de um critério para a classificação como subdesenvolvido, havendo além disso a dificuldade, que não seria pequena, para o estabelecimento da quota que cada um deveria receber com justiça. Mais grave, entretanto, é a atitude paternalista desse critério, pois, em lugar de assegurar os meios para que os Estados mais pobres se desenvolvam com seus próprios recursos, criaria uma situação de permanente dependência, estabelecendo uma discriminação humilhante.

De qualquer modo, porém, fica também evidente, pelo conjunto do plano, a intenção de encontrar soluções jurídicas, inspiradas na aplicação de princípios jurídicos, consubstanciadas em instrumentos jurídicos e, além disso tudo, entregues à tutela do uma corte internacional.

31. Como tem sido reafirmado por teóricos e estadistas, não se pode pretender, pelo menos até agora, que tenha sido superado o "egoísmo dos Estados" Assim, pois, o que explica que uma das primeiras potências mundiais tome a iniciativa de propor soluções jurídicas, sacrificando parte de seus interesses, sem nenhum apelo à sua superioridade

200 milhas o mar territorial norte-americano. Essa iniciativa poderia ser interpretada como manobra tática, visando dar aos Estados Unidos uma posição mais favorável para negociações. Mesmo com tal sentido, entretanto, parece pouco provável que o governo norte-americano apoie o projeto, por vários motivos. Além de contrariar a posição reiterada e até aqui intransigente, do Estado norte-americano, recusando o mar territorial de 200 milhas, sua mudança de atitude iria, fatalmente, consolidar a posição dos que já ampliaram, unilateralmente, seu respectivo mar territorial, encorajando-os a novas iniciativas. De qualquer modo, porém, a existência do projeto não pode ser ignorada, pura e simplesmente, devendo-se acompanhar atentamente sua tramitação, podendo mesmo ser explorada taticamente sua propositura, como prova de que a Câmara de Representantes dos Estados Unidos não é totalmente infensa às 200 milhas. Outro projeto, propondo a ampliação do mar territorial dos Estados Unidos para 200 milhas, foi apresentado ao Senado norte-americano em dezembro de 1973, cabendo, quanto a este projeto, as mesmas observações feitas quanto ao projeto em curso na Câmara de Representantes. O que pode ser ressaltado de original é que o autor do novo projeto, o Senador Warren Magnuson, presidente da Comissão Comercial do Senado, afirma ter o apoio de todos os sindicatos pesqueiros dos Estados Unidos, os quais sempre se opuseram às ampliações unilaterais do mar territorial, pretendendo até que o governo norte-americano adotasse represálias contra essas ampliações. 
de força? A explicação dessa atitude está justamente no reconhecimento de uma nova situação mundial, em que os meios violentos perderam sua antiga eficácia e em que também os pequenos Estados, mesmo que pobres e desprovidos de recursos militares, se apoiam numa nova força, que lhes permite afrontar os grandes e poderosos. Essa nova força é a consciência jurídica internacional, que já não mais permite o equacionamento dos problemas internacionais a partir da simples constatação do poderio bélico, mas exige a consideração de todas as vontades e a busca de soluções justas.

Embora não se possa concluir que as relações internacionais já estejam inteiramente disciplinadas pelo Direito, é inegável a intensificação do apelo a soluções jurídicas, o que é altamente benéfico e poderá resultar num irreversível aumento da eficácia do Direito Internacional.

VI. CONCLUSÕES FINAIS.

32. Com base em tudo quanto foi exposto, relativamente à situação geral do problema do mar territorial e aos aspectos particulares que ele tem apresentado no Brasil, podem-se estabelecer algumas conclusões quanto às perspectivas oferecidas pela posição brasileira e quanto à disciplina do assunto em âmbito mundial.

No que diz respeito ao Brasil, três são os pontos fundamentais, a saber:

a) A decisão brasileira, ampliando para duzentas milhas o mar territorial, ainda não tem a sanção do Direito Internacional, uma vez que não reflete uma orientação consagrada nos tratados, no costume, ou na jurisprudência. Na realidade, essa decisão contrariou regras geralmente aceitas e atingiu direitos de outros Estados, até então reconhecidos pelo próprio Estado Brasileiro, sobretudo por significar a apropriação de uma parcela do alto mar, tido como objeto de domínio comum de todos os Estados. De um ponto de vista rigorosamente formal, a ampliação unilateral do mar territorial, com o consequente aumento do próprio território e o alargamento do âmbito de sua própria soberania, equivale a um ato de anexação territorial, embora por via pacífica $\theta$ atingindo um espaço do domínio comum de todos, não exclusivo de algum Estado. Esse é o 
ponto juridicamente falho na posição brasileira, havendo, entretanto, inúmeros argumentos ponderáveis que podem modificar o próprio tratamento jurídico do assunto.

b) O segundo aspecto importante a ser ressaltado, quanto à posição adotada pelo Brasil, é que ela não foi pioneira, em qualquer sentido, havendo inúmeros precedentes em relação a cada aspecto que possa ser atacado. Com efeito, quanto à unilateralidade da decisão de ampliar o mar territorial, em prejuízo do domínio comum de terceiros, verifica-se que para o mesmo fim, ou para outros, diversos Estados procederam da mesma forma. Com efeito, quando os Estados Unidos da América ampliaram a sua área de segurança, unilateralmente, invadiram território comum de todos os Estados e impuseram a estes inúmeras limitações, reduzindo-lhes os direitos. E quando outros Estados ampliaram o seu mar territorial por decisão também unilateral, aumentando-o para cincoenta ou para duzentas milhas, criaram vários precedentes, que o Brasil acompanhou sem inovar Mesmo no caso do estabelecimento de amplas "zonas de pesca", por decisão unilateral, ocorreu a restrição de direitos de terceiros, ainda que sem a amplitude da extensão do mar territorial.

c) Um terceiro ponto importante é que a iniciativa brasileira pode estar situada no nascedouro de um novo costume em formação. $\mathrm{Na}$ realidade, nenhum costume nasce como tal, havendo a necessidade da reiteração de certa prática para que ela se torne clara e tradicional, impondo-se como norma costumeira.

Assim sendo, desde que um número considerável de Estados latino-americanos consiga manter durante longo tempo, pelo menos dez anos, seu controle exclusivo sobre as duzentas milhas, já poderá, então, ser sustentada a tese da existência de um costume regional. Como é óbvio, os grandes interessados em obstar esse resultado irão procurar evitá-lo, cabendo ao político, não ao jurista, analisar esse aspecto do conflito.

33. Quanto à situação geral do problema do mar territorial, são as seguintes, em síntese, as posições dos Estados:

a) alguns sustentam a legitimidade da extensão para duzentas milhas, ampliando para este limite sua soberania, com o que esta implica. 
b) outros rejeitam qualquer exclusividade além de doze milhas, admitindo esta medida para o mar territorial, mas recusando que além dela qualquer Estado possa ter um direito exclusivo, ou o proveito exclusivo das riquezas.

c) uma posição intermediária aceita o mar territorial de doze milhas, admitindo que além desse limite os Estados possam ter preferências ou direitos exclusivos, desde que estes se refiram apenas a determinada área de interesses, como a segurança, ou a pesca, ou a exploração do sub-solo marítimo etc. É nesta posição que se pode enquadrar a proposta do mar territorial de doze milhas, com mais cento e oitenta e oito milhas de mar patrimonial.

d) além dessas há uma série bastante heterogênea de posições, sempre em função dos interesses específicos de cada Estado.

34. Como última conclusão pode-se ressaltar, uma vez mais, a existência de uma tendencia no sentido de intensificar a disciplina jurídica das relações internacionais, com o acréscimo de que, no tocante ao mar territorial, isso beneficia especialmente os Estados mais pobres e mais fracos.

Com efeito, se o problema do mar territorial for colocado em termos estritamente políticos, fazendo as soluções dependerem do poderio bélico de cada Estado, os menos desenvolvidos, que são os mais necessitados, jamais poderão obter a satisfação de seus interesses. Se, em lugar disso, prevalecer o desejo de encontrar soluções segundo o Direito, os pequenos Estados serão iguais aos grandes em força jurídica, havendo a esperança de que consigam melhorar os seus padrões materiais preservando sua independência . 